\title{
Histidine tracts in human transcription factors: insight into metal ion coordination ability
}

\author{
Aleksandra Hecel $^{1}$ • Joanna Wątły ${ }^{1}$. Magdalena Rowińska-Żyrek ${ }^{1}$ • Jolanta Świątek-Kozłowska ${ }^{2}$. \\ Henryk Kozłowski ${ }^{2,3}$
}

Received: 29 September 2017 / Accepted: 3 November 2017 / Published online: 7 December 2017

(c) The Author(s) 2017. This article is an open access publication

\begin{abstract}
Consecutive histidine repeats are chosen both by nature and by molecular biologists due to their high affinity towards metal ions. Screening of the human genome showed that transcription factors are extremely rich in His tracts. In this work, we examine two of such His-rich regions from forkhead box and MAFA proteins-MB3 (contains 18 His) and MB6 (with 21 His residues), focusing on the affinity and binding modes of $\mathrm{Cu}^{2+}$ and $\mathrm{Zn}^{2+}$ towards the two His-rich regions. In the case of $\mathrm{Zn}^{2+}$ species, the availability of imidazole nitrogen donors enhances metal complex stability. Interestingly, an opposite tendency is observed for $\mathrm{Cu}^{2+}$ complexes at above physiological $\mathrm{pH}$, in which amide nitrogens participate in binding.
\end{abstract}

Keywords Binding affinity $\cdot$ Ligand binding $\cdot$ Thermodynamics $\cdot$ Homeostasis $\cdot$ Mass spectrometry $\cdot$ Peptide

\section{Introduction}

Histidine-rich (His-rich) motifs are present in many peptide domains and consist of multiple His residues, which can efficiently bind metal ions [1-4]. They have been found in a variety of proteins such as metal transporters $[5,6]$, prion proteins [7-11], bacterial nickel chaperones [12-18], snake venom proteins [19, 20], antimicrobial peptides [21, 22], histidine-rich glycoproteins (HRG) [23, 24] and many others of biological significance. Repeats of a different number of histidines are common also in commercially used immobilized metal affinity chromatography (IMAC) and they are

Electronic supplementary material The online version of this article (https://doi.org/10.1007/s00775-017-1512-x) contains supplementary material, which is available to authorized users.

Aleksandra Hecel

aleksandra.hecel@chem.uni.wroc.pl

Henryk Kozłowski

henryk.kozlowski@chem.uni.wroc.pl

1 Faculty of Chemistry, University of Wroclaw, F. Joliot-Curie 14, 50-383 Wrocław, Poland

2 Public Higher Medical Professional School in Opole, Katowicka 68, 45-060 Opole, Poland

3 Wroclaw Research Centre EIT+, Stabłowicka 147, 54-066 Wrocław, Poland known as His-tags [25].They are specific type of His-rich sequences, usually containing from six to nine subsequent histydyl residues and used in molecular biology for purification of recombinant proteins [26].

The widespread occurrence of histidine repeats in nature is very exciting from the evolutional, biological, chemical and medical point of view. Understanding their interactions with metal ions is not only chemically intriguing, but is also the fundamental step towards using them in potential medicinal applications [27-29]. Single amino acid repeats are extremely important in eukaryotic proteins [30]. This homopolymeric tracts are known to play important structural or even functional roles. Indeed, there is an over representation of single amino acid repeat (SAR)-containing proteins among transcription factors, kinases and proteins required for development [31-34]. Among homopolymeric tracts, sequences with histidine-tag (His-tag) motif (special sequences containing a huge number of neighboring His residues) are relatively rare [34]. These repeats may fulfill different roles, affecting protein conformation and enzymatic activity-His-tags are found in $\mathrm{Zn}$-finger domains involved in interactions between nucleic acids and proteins [35]; flexible His tracts have been found in transcriptional regulators $[36,37]$ and as nuclear speckle-targeting signals [38].

86 proteins in the human genome contain stretches of five or more consecutive histidine residues; most of these proteins have functions related with RNA synthesis; their 
mechanism of action is not clear [39]. Our recent studies on different 'poly-His' region interactions with $\mathrm{Cu}^{2+}$ and $\mathrm{Zn}^{2+}$ $[1,2,4,40-42]$ show that they form thermodynamically stable complexes with so-called polymorphic binding states, with the metal "moving back and forth" along such regions $[1,2]$. It is worth to notice that in many cases, metal ion binding induced the formation of an $\alpha$-helical structure [2].

Understanding the relationship between metal ion binding, structure and function is one of the most important pillars of bioinorganic chemistry. Sequences with consecutive His repeats have been chosen both by nature and by molecular biologists as metal chelators due to their high affinity towards metal ions. Understanding $\mathrm{Cu}^{2+}$ and $\mathrm{Zn}^{2+}$ coordination to our studied sequences will be an important input to the bioinorganic chemistry of the studied metals that allows a better understanding of the proper design of His-tags. To the best of our knowledge, thermodynamics of metal complexes with protein sequences containing 18 and 22 His residues have not yet been studied.

This work explains the interactions of $\mathrm{Cu}^{2+}$ and $\mathrm{Zn}^{2+}$ with two multihistidine peptide fragments from transcription factors: MB3 (Ac-HHASHGHHNSHHPQHHHHHHHHHHH$\mathrm{NH}_{2}$ ), the 33-57 region of FOXG1B (forkhead box) protein, which plays an important role in the regional subdivision of the developing brain [43] and MB6 (Ac-HHHGAHHAAHHHHAAHHHHHHHHHSHGGAGHGGGAGHH-NH ${ }_{2}$ ), a 184-219 region of the MAFA protein, which specifically activates insulin expression [44, 45]; phosphorylation is required for its oncogenic activity-it can function either as an oncogene or as a tumor suppressor, depending on the cell context [46]. A combination of mass spectrometric, potentiometric and spectroscopic studies show the coordination abilities of these ligands towards $\mathrm{Cu}^{2+}$ and $\mathrm{Zn}^{2+}$ ions.

\section{Experimental}

\section{Materials}

The N- and C-terminally protected MB3 (Ac-HHASHGHHNSHHPQHHHHHHHHHHH- $\mathrm{NH}_{2}$ ) and MB6 (Ac-HHHGAHHA AHHHHAAHHHHHHHHHSHGGAGHGGGAGHH-NH${ }_{2}$ ) fragments were purchased from KareBayBiochem (USA) (certified purity 98\%) and used as received. Their purity was checked potentiometrically. $\mathrm{Cu}\left(\mathrm{ClO}_{4}\right)_{2}$ and $\mathrm{Zn}\left(\mathrm{ClO}_{4}\right)_{2}$ were extra pure products (SigmaAldrich); concentration of their stock solutions was determined by ICP-MS. The carbonate-free stock solution of $0.1 \mathrm{~mol} \mathrm{dm}^{-3} \mathrm{NaOH}$ was potentiometrically standardized with potassium hydrogen phthalate (both Sigma-Aldrich). All samples were prepared with freshly doubly distilled water. The ionic strength $(I)$ was adjusted to $0.1 \mathrm{M}$ by addition of $\mathrm{NaClO}_{4}$ (Sigma-Aldrich).

\section{Mass spectrometric measurements}

High-resolution mass spectra were obtained on Bruker MicrOTOF-Q spectrometers (Bruker Daltonik, Bremen, Germany) equipped with an Apollo II electrospray ionization source with an ion funnel. Spectrometer was used for measurements on $\mathrm{Cu}^{2+}$ and $\mathrm{Zn}^{2+}$ complexes (with both ligands) in the range of positive values. The instrumental parameters were as follows: scan range $m / z, 250-2000$; dry gas nitrogen; temperature $200{ }^{\circ} \mathrm{C}$; ion source voltage $4500 \mathrm{~V}$; collision energy $10 \mathrm{eV}$. The $\mathrm{Cu}^{2+}$ and $\mathrm{Zn}^{2+}$ complexes [(metal:ligand stoichiometry of 1:1.2 and 1:2, respectively), [ligand $]_{\mathrm{tot}}=2 \times 10^{-4} \mathrm{M}$ ] were prepared in a $1: 1 \mathrm{MeOH} / \mathrm{H}_{2} \mathrm{O}$ mixture at $\mathrm{pH} 6$ (by adding an appropriate amount of $\mathrm{NaOH}$ ). The samples were infused at a flow rate of $3 \mu \mathrm{L} / \mathrm{min}$. Before each experiment, the instrument was calibrated externally with the Tunemix mixture. Data were processed by application of the Bruker Compass DataAnalysis 4.0. program.

\section{Potentiometric measurements}

Stability constants for proton and $\mathrm{Cu}^{2+}$ and $\mathrm{Zn}^{2+}$ complexes were calculated basing on two titration curves carried out over the $\mathrm{pH}$ range $2-11$ at $298 \mathrm{~K}$ in a total volume of $3 \mathrm{~cm}^{3}$. The potentiometric titrations were performed using a Dosimat 665 Metrohm titrator connected to a Metrohm $691 \mathrm{pH}$-meter and a Metrohm LL Unitrode glass electrode. The glass cell was equipped with a magnetic stirring system, a microburet delivery tube and an inlet-outlet tube for argon. The $\mathrm{pH}$-metric titrations were performed in $30 \%$ DMSO solution of $\mathrm{HClO}_{4}$ at $0.1 \mathrm{M}$ $\mathrm{NaClO}_{4}$ ionic strength (both ligands are insoluble in pure water solution). Solutions were titrated with $0.1 \mathrm{M}$ carbonate-free $\mathrm{NaOH}$. Electrodes were calibrated daily for hydrogen ion concentration by titrating $\mathrm{HClO}_{4}$ with $\mathrm{KOH}$ in the same experimental conditions as above. Purities and the exact concentrations of ligand solutions were determined by the Gran method [47]. The ligand concentration was $0.5 \mathrm{mM}$. Metal ions concentration were $0.42 \mathrm{mM} \mathrm{Cu}^{2+}$ and $0.25 \mathrm{mM} \mathrm{Zn}^{2+}$, respectively. The metal-to-ligand ratio was $1: 1.2$ for $\mathrm{Cu}^{2+}$ complexes and $1: 2$ for $\mathrm{Zn}^{2+}$ complexes. HYPERQUAD2006 and SUPERQUAD programs were used for the stability constant calculations [48]. Standard deviations were computed by HYPERQUAD 2006 and refer to random errors only. The constants for hydrolytic $\mathrm{Cu}^{2+}$ and $\mathrm{Zn}^{2+}$ species were used [49, 50]. The speciation and competition diagrams were computed with the HySS program [51]. 
Table 1 Potentiometric and spectroscopic data for $\mathrm{Cu}^{2+}-\mathrm{MB} 3$ complexes

\begin{tabular}{|c|c|c|c|c|c|c|c|c|}
\hline \multirow[t]{2}{*}{ Complex species } & \multirow[t]{2}{*}{$\log \beta$} & \multicolumn{2}{|c|}{ UV-Vis } & \multicolumn{2}{|l|}{$\mathrm{CD}$} & \multicolumn{2}{|l|}{ EPR } & \multirow[t]{2}{*}{ Proposed donors } \\
\hline & & $\lambda(\mathrm{nm})$ & $\varepsilon\left(\mathrm{M}^{-1} \mathrm{~cm}^{-1}\right)$ & $\lambda(\mathrm{nm})$ & $\Delta \varepsilon\left(\mathrm{M}^{-1} \mathrm{~cm}^{-1}\right)$ & $A_{\|}[\mathrm{G}]$ & $g_{\|}$ & \\
\hline \multicolumn{9}{|c|}{$\mathrm{Cu}^{2+}-\mathrm{Ac}-\mathrm{HHASHGHHNSHHPQHHHHHHHHHHH-NH}{ }_{2}$} \\
\hline$\left[\mathrm{CuH}_{15} \mathrm{~L}\right]^{15+}$ & $101.75(2)$ & 620 & 50.56 & 527 & 0.80 & 181.1 & 2.245 & $3 \mathrm{~N}_{\mathrm{im}}$ \\
\hline \multirow[t]{2}{*}[\mathrm{CuH}_{13}\mathrm{L}]{$^{13+}$} & $92.57(3)$ & 568 & 68.00 & 534 & 1.51 & 190.1 & 2.244 & $3 \mathrm{~N}_{\mathrm{im}}, 1 \mathrm{~N}^{-}$ \\
\hline & & 315 & 222.93 & 313 & -0.71 & & & \\
\hline \multirow[t]{2}{*}[\mathrm{CuH}_{10}\mathrm{L}]{$^{10+}$} & $76.87(3)$ & 568 & 70.42 & 534 & 1.64 & 192.1 & 2.244 & $3 \mathrm{~N}_{\mathrm{im}}, 1 \mathrm{~N}^{-}$ \\
\hline & & 316 & 227.28 & 316 & -0.78 & & & \\
\hline \multirow[t]{2}{*}[\mathrm{CuH}_{7}\mathrm{L}]{$^{7+}$} & $59.33(3)$ & 571 & 74.48 & 535 & 1.68 & 192.8 & 2.241 & $3 \mathrm{~N}_{\mathrm{im}}, 1 \mathrm{~N}^{-}$ \\
\hline & & 317 & 240.49 & 317 & -0.79 & & & \\
\hline$\left[\mathrm{CuH}_{5} \mathrm{~L}\right]^{5+}$ & 46.66 (4) & & & & & & & \\
\hline$\left[\mathrm{CuH}_{3} \mathrm{~L}\right]^{3+}$ & $33.11(5)$ & & & & & & & \\
\hline$\left[\mathrm{CuH}_{2} \mathrm{~L}\right]^{2+}$ & $25.75(6)$ & & & & & & & \\
\hline$[\mathrm{CuHL}]^{+}$ & $17.04(13)$ & & & & & & & \\
\hline$[\mathrm{CuL}]$ & $8.61(5)$ & & & & & & & \\
\hline \multirow[t]{4}{*}[\mathrm{CuH}_{-2}\mathrm{L}]{$^{2-}$} & $-11.73(6)$ & 551 & 111.68 & 637 & 1.35 & 184.1 & 2.216 & $2 \mathrm{~N}_{\mathrm{im}}, 2 \mathrm{~N}^{-}$ \\
\hline & & & & 507 & -0.57 & & & \\
\hline & & & & 406 & 0.20 & & & \\
\hline & & & & 351 & -0.19 & & & \\
\hline
\end{tabular}

$\mathrm{Cu}^{2+}$ to ligand ratio of $1: 1 \cdot 2 .\left[\mathrm{Cu}^{2+}\right]=0.83 \mathrm{mM}$

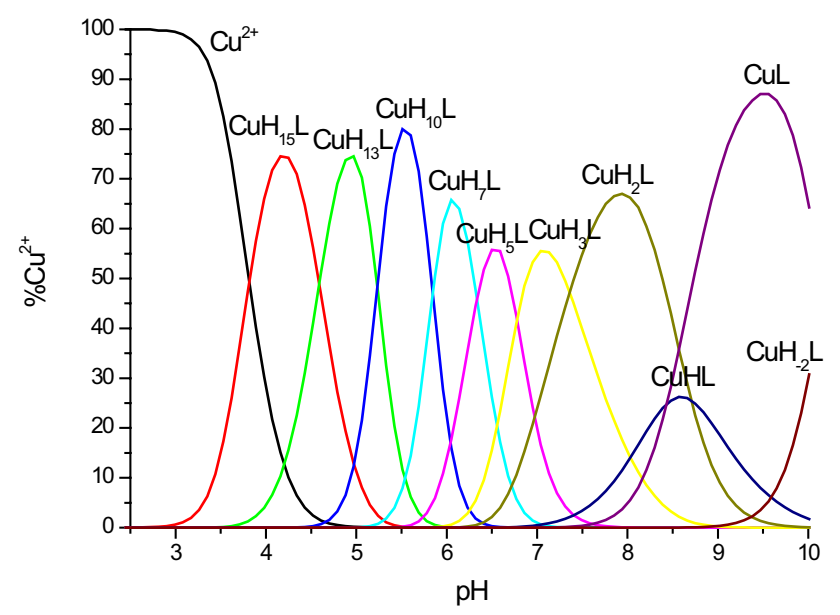

Fig. 1 Species distribution diagram for $\mathrm{Cu}^{2+}-\mathrm{MB} 3$ complexes at 1:1.2 $\mathrm{Cu}^{2+} /$ peptide ratio; $T=298 \mathrm{~K} ; c_{\text {peptide }}=0.5 \mathrm{mM}$ (for clarity, the charges on the speciation plots were omitted)

\section{Spectroscopic studies}

Circular dichroism (CD) spectroscopy experiments were performed on a spectropolarimeter Jasco-J-750 at $298 \mathrm{~K}$ in a $10 \mathrm{~mm}$ quartz cell. The spectral range was $250-800 \mathrm{~nm}$. Samples were prepared in $4.0 \mathrm{mM} \mathrm{HClO}_{4}(30 \% \mathrm{DMSO}$ solutions containing $0.1 \mathrm{M} \mathrm{NaClO}_{4}$ ionic strength). Ligand concentration was $1 \mathrm{mM}$ and $\mathrm{Cu}^{2+}$ to ligand molar ratio was $1: 1.2$. The direct $\mathrm{CD}$ measurements $(\Theta)$ were converted to mean residue molar ellipticity $(\Delta \varepsilon)$ using Jasco Spectra Manager.

The absorption spectra in the UV-Vis region were recorded at $298 \mathrm{~K}$ on a Varian Cary 300 Bio spectrophotometer in $10 \mathrm{~mm}$ path length quartz cell. The spectral range was $200-800 \mathrm{~nm}$. The samples were prepared in $4.0 \mathrm{mM}$ $\mathrm{HClO}_{4}\left(30 \%\right.$ DMSO solutions containing $0.1 \mathrm{M} \mathrm{NaClO}_{4}$ ionic strength). Ligand concentration was $1 \mathrm{mM}$ and $\mathrm{Cu}^{2+}$ to ligand molar ratio was 1:1.2.

Electron paramagnetic resonance (EPR) spectra were recorded in liquid nitrogen on a Bruker ELEXSYS E500 CW-EPR spectrometer at X-band frequency $(9.5 \mathrm{GHz})$ and equipped with an ER 036TM NMR Teslameter and an E41 $\mathrm{FC}$ frequency counter. The ligands were prepared in $30 \%$ DMSO solution of $\mathrm{HClO}_{4}$ at $I=0.1 \mathrm{M}\left(\mathrm{NaClO}_{4}\right)$. The concentration of $\mathrm{Cu}^{2+}$ was $1 \mathrm{mM}$ and the $M: L$ molar ratio was $1: 1.2$. In the EPR experiment, a natural mixture of ${ }^{63} \mathrm{Cu}$ and ${ }^{65} \mathrm{Cu}$ isotopes was used, both of them with nuclear spin $I=3 / 2$. Ethylene glycol (30\%) was used as a cryoprotectant for EPR measurements. The EPR parameters were analyzed by computer simulation of the experimental spectra using WIN-EPR SIMFONIA software, version 1.2 (Bruker). The $\mathrm{pH}$ was adjusted with appropriate amounts of $\mathrm{HCl}$ and $\mathrm{NaOH}$ solutions. A mixture of copper isotopes was used, which never give separate signals in case of nitrogen and/ or oxygen coordinating donors, but lead to broadening of the signals; the line around perpendicular component of $\mathrm{g}$ tensor is also broadened due to poorly resolved copper hyperfine splitting. This resonance transition reveals the best 
resolution of ${ }^{14} \mathrm{~N}$ hyperfine splitting, what is well known from the [52-58]. Since both DMSO and water solvents are very improper for the observation of nitrogen hyperfine splitting (leading to strong absorption of microwaves and giving very weak EPR spectra), frozen solutions were used.

\section{Results and discussion}

Structural and thermodynamic properties of $\mathrm{Cu}^{2+}-$ and $\mathrm{Zn}^{2+}-\mathrm{MB} 3$ and MB6 complexes were studied by mass spectrometric, potentiometric calculations and a variety of spectroscopic techniques: UV-Vis, CD and EPR spectroscopy. Potentiometric titrations were the basis for the determination of precise stability constants and $\mathrm{pH}$-dependent species distribution diagrams and combined spectroscopic techniques results allowed to determine the copper and zinc binding modes and the coordination geometries of these species formed in solution.

\section{Protonation constants of the MB3 (Ac-HHASHGHHN- SHHPQHHHHHHHHHHH-NH ${ }_{2}$ ) and MB6 (AC-HHH- GAHHAAHHHHAAHHHHHHHHHSHGGAGHGG- GAGHH-NH ${ }_{2}$ ) ligands}

Each of the peptide MB3 and MB6 was protected in the $\mathrm{N}$-terminus by acetylation and in the C-terminus by amidation. MB3 consists of eighteen possible sites of protonations-all of them are assigned to the eighteen histidine residues (Table S1). The MB6 peptide consists of 22 sites (Table S1) involved in acid-base equilibria, which correspond to imidazole nitrogen atoms of histidine residues. Because of the enormous number of histidine residues in

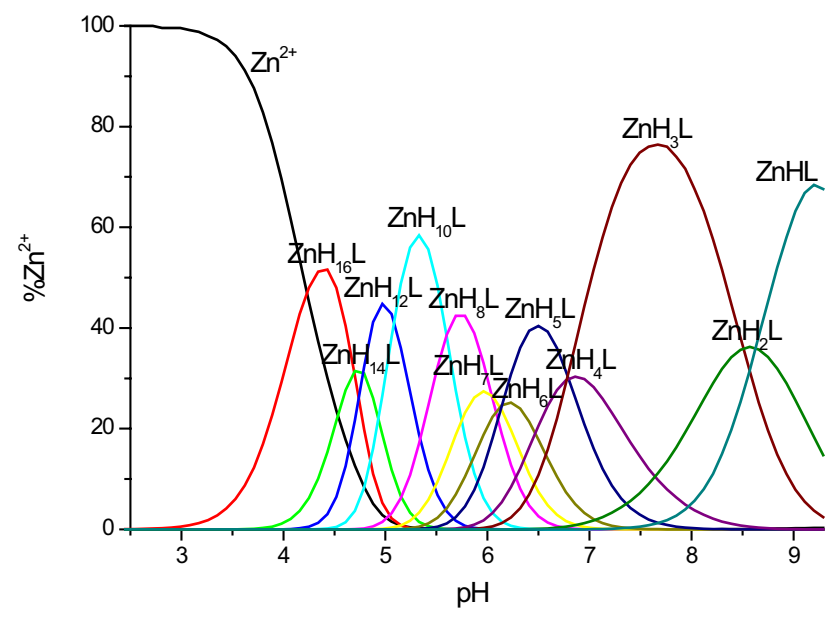

Fig. 2 Species distribution diagram for $\mathrm{Zn}^{2+}-\mathrm{MB} 3$ complexes at 1:2 $\mathrm{Zn}^{2+} /$ peptide ratio; $T=298 \mathrm{~K} ; c_{\text {peptide }}=0.5 \mathrm{mM}$. A higher $\mathrm{Zn}^{2+} /$ peptide ratio triggered precipitation at $\mathrm{pH}$ above 8.5 . For clarity, charges on the speciation plots were omitted
Table 2 Formation constants of $\mathrm{Zn}^{2+}-\mathrm{MB} 3$ complexes at $298 \mathrm{~K}$ and $I=0.1 \mathrm{M}\left(\mathrm{NaClO}_{4}\right)$

\begin{tabular}{lrl}
\hline Complex species & \multicolumn{1}{l}{$\log \beta$} & $\mathrm{pKa}$ \\
\hline$\left[\mathrm{ZnH}_{16} \mathrm{~L}\right]^{16+}$ & $104.69(2)$ & \\
{$\left[\mathrm{ZnH}_{14} \mathrm{~L}\right]^{14+}$} & $95.31(2)$ & \\
{$\left[\mathrm{ZnH}_{12} \mathrm{~L}\right]^{12+}$} & $85.75(2)$ & \\
{$\left[\mathrm{ZnH}_{10} \mathrm{~L}\right]^{10+}$} & $75.58(3)$ & 6.04 \\
{$\left[\mathrm{ZnH}_{8} \mathrm{~L}\right]^{8+}$} & $64.38(4)$ & 6.12 \\
{$\left[\mathrm{ZnH}_{7} \mathrm{~L}\right]^{7+}$} & $58.34(7)$ & 6.15 \\
{$\left[\mathrm{ZnH}_{6} \mathrm{~L}\right]^{6+}$} & $52.22(9)$ & 6.79 \\
{$\left[\mathrm{ZnH}_{5} \mathrm{~L}\right]^{5+}$} & $46.07(5)$ & 6.78 \\
{$\left[\mathrm{ZnH}_{4} \mathrm{~L}\right]^{4+}$} & $39.28(5)$ & 8.51 \\
{$\left[\mathrm{ZnH}_{3} \mathrm{~L}\right]^{3+}$} & $32.50(4)$ & 8.63 \\
{$\left[\mathrm{ZnH}_{2} \mathrm{~L}\right]^{2+}$} & $23.99(4)$ & \\
{$\left[\mathrm{ZnHL}^{+}\right.$} & $15.36(6)$ & \\
\hline
\end{tabular}

Standard deviations in the last figure are shown in parentheses

presented sequences, not all protonation constants could be precisely determined. During potentiometric measurements, His residues deprotonate in the $\mathrm{pH}$ range of $4-8$ and it is not possible to observe (or rather to precisely calculate) the $\mathrm{pKa}$ of each from - they probably deprotonate in pairs. The $\log \beta$ values obtained from potentiometric titration analysis are typical values of histidine residues in poly-His systems $[1,4]$. The distribution diagrams of investigated ligands are presented on Figures S1 and S2.

\section{Metal binding stoichiometry of the $\mathrm{Cu}^{2+} / \mathrm{Zn}^{2+}-\mathrm{MB3}$ system}

Electrospray ionization mass spectrometry (ESI-MS) confirmed the purity of the studied MB3 ligand (Ac-HHASHGHHNSHHPQHHHHHHHHHHH-NH ${ }_{2}$ ) and showed the metal binding stoichiometry at $\mathrm{pH} 6$, indicating that equimolar species were present under the studied conditions (e.g. $\mathrm{m} / \mathrm{z}$ values at 808.58 and 647.67 correspond to $\left[\mathrm{CuLH}_{4}\right]^{4+}$ and $\left[\mathrm{ZnLH}_{5}\right]^{5+}$ complex species, respectively) (Figure $\mathrm{S} 1) . \mathrm{m} / \mathrm{z}$ values at $793.10,634.68$ and 529.07 correspond to $\left[\mathrm{LH}_{4}\right]^{4+},\left[\mathrm{LH}_{5}\right]^{5+},\left[\mathrm{LH}_{6}\right]^{6+}$ ligand species, respectively (Figure S1 A).

\section{$\mathrm{Cu}^{2+}-\mathrm{MB} 3$ system}

Potentiometric titrations of $\mathrm{Cu}^{2+}-\mathrm{MB} 3$ complexes were carried out to evaluate the corresponding complex formation constants and the distribution diagram (Table 1, Fig. 1).

In the studied $\mathrm{pH}$ range (2-10), the most accurate fit of titration curves for the $\mathrm{Cu}^{2+}-\mathrm{MB} 3 \mathrm{com}$ plexes indicates the presence of nine equimolar species: $\left[\mathrm{CuH}_{15} \mathrm{~L}\right]^{15+},\left[\mathrm{CuH}_{13} \mathrm{~L}\right]^{13+},\left[\mathrm{CuH}_{10} \mathrm{~L}\right]^{10+},\left[\mathrm{CuH}_{7} \mathrm{~L}\right]^{7+}$, $\left[\mathrm{CuH}_{5} \mathrm{~L}\right]^{5+},\left[\mathrm{CuH}_{3} \mathrm{~L}\right]^{3+},\left[\mathrm{CuH}_{2} \mathrm{~L}\right]^{2+},[\mathrm{CuHL}]^{+},[\mathrm{CuL}]$, 


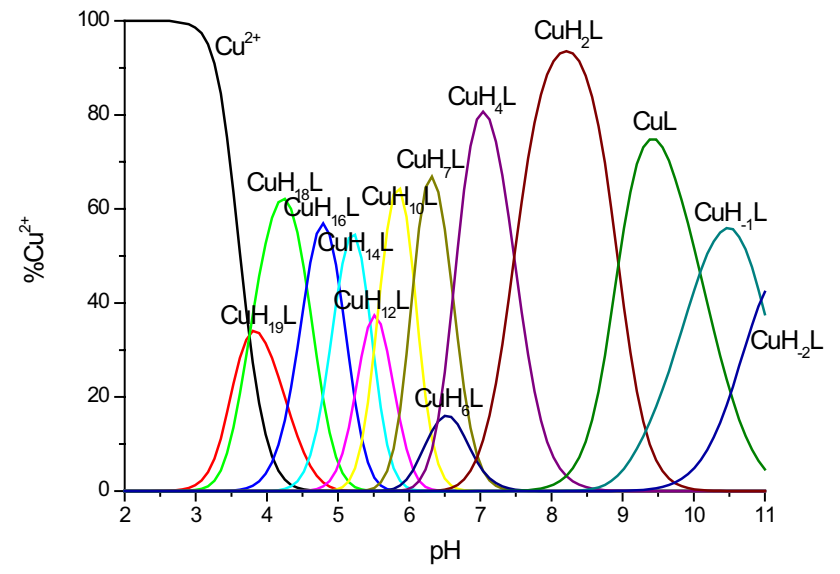

Fig. 3 Species distribution diagram for $\mathrm{Cu}^{2+}-\mathrm{MB} 6$ complexes at $1: 1.2 \mathrm{Cu}^{2+} /$ peptide ratio; $T=298 \mathrm{~K} ; c_{\text {peptide }}=0.5 \mathrm{mM}$ (for clarity, the charges on the speciation plots were omitted)
$\left[\mathrm{CuH}_{-2} \mathrm{~L}\right]^{2-}$ (Fig. 1). The first species of this complex occurs at $\mathrm{pH} 4.2$ and last of them achieves a maximum concentrations at $\mathrm{pH}$ around 10. Careful study of obtained experimental potentiometric and spectroscopic studies allowed a detailed thermodynamic and structural characterization of the complex, showing the number and type of coordinated atoms from the peptide (Table 1).

The first complex detected at low $\mathrm{pH}$ is $\left[\mathrm{CuH}_{15} \mathrm{~L}\right]^{15+}$, with a maximum concentration at $\mathrm{pH} 4.2$ (Fig. 1). It is most probable that in this complex three imidazole residues are coordinated to the $\mathrm{Cu}^{2+}$ ion [59]. The coordination of $\mathrm{Cu}^{2+}$ to three imidazole nitrogens is supported by the $\mathrm{d}-\mathrm{d}$ band at $620 \mathrm{~nm}$ at $\mathrm{pH} 3.87$ (Figure S4). The shift of the $\mathrm{d}-\mathrm{d}$ band from 620 to $568 \mathrm{~nm}$ in $\mathrm{pH}$ range 4-6 suggests the coordination of a fourth nitrogen atom resulting in the $\left\{3 \mathrm{~N}_{\mathrm{im}}\right.$, $\left.1 \mathrm{~N}^{-}\right\}$binding mode for the $\left[\mathrm{CuH}_{13} \mathrm{~L}\right]^{13+},\left[\mathrm{CuH}_{10} \mathrm{~L}\right]^{10+}$ and $\left[\mathrm{CuH}_{7} \mathrm{~L}\right]^{7+}$ species. The coordination of an amide nitrogen is provided by the appearance of intense $\mathrm{d}-\mathrm{d}$ bands in $\mathrm{CD}$ spectra at $530-650 \mathrm{~nm}$ range (Figure S5). The coordination

Table 3 Potentiometric and spectroscopic data for $\mathrm{Cu}^{2+}-\mathrm{MB} 6$ complexes

\begin{tabular}{|c|c|c|c|c|c|c|c|c|}
\hline \multirow[t]{2}{*}{ Complex species } & \multirow[t]{2}{*}{$\log \beta$} & \multicolumn{2}{|c|}{ UV-Vis } & \multicolumn{2}{|l|}{$\mathrm{CD}$} & \multicolumn{2}{|l|}{ EPR } & \multirow[t]{2}{*}{ Proposed donors } \\
\hline & & $\lambda(\mathrm{nm})$ & $\varepsilon\left(\mathrm{M}^{-1} \mathrm{~cm}^{-1}\right)$ & $\lambda(\mathrm{nm})$ & $\Delta \varepsilon\left(\mathrm{M}^{-1} \mathrm{~cm}^{-1}\right)$ & $A_{\|}[\mathrm{G}]$ & $g_{\|}$ & \\
\hline \multicolumn{9}{|c|}{$\mathrm{Cu}^{2+}-\mathrm{Ac}-\mathrm{HHHGAHHAAHHHHAAHHHHHHHHHSHGGAGHGGGAGHH-NH}{ }_{2}$} \\
\hline$\left[\mathrm{CuH}_{19} \mathrm{~L}\right]^{19+}$ & $123.36(6)$ & 687 & 37.80 & & & & & $2 \mathrm{~N}_{\mathrm{im}}$ \\
\hline$\left[\mathrm{CuH}_{18} \mathrm{~L}\right]^{18+}$ & $119.60(2)$ & 618 & 56.70 & 533 & 0.64 & 186.3 & 2.24 & $3 \mathrm{~N}_{\mathrm{im}}$ \\
\hline \multirow[t]{2}{*}[\mathrm{CuH}_{16}\mathrm{L}]{$^{16+}$} & $110.48(3)$ & 571 & 68.42 & 536 & 1.27 & & & $2 \mathrm{~N}_{\mathrm{im}}, 1 \mathrm{~N}^{-}$ \\
\hline & & 311 & 253.15 & 316 & -0.41 & & & \\
\hline \multirow[t]{2}{*}[\mathrm{CuH}_{14}\mathrm{L}]{$^{14+}$} & $100.46(2)$ & 569 & 71.57 & 533 & 1.55 & 186.3 & 2.24 & $2 \mathrm{~N}_{\mathrm{im}}, 1 \mathrm{~N}^{-}$ \\
\hline & & 311 & 255.12 & 317 & -0.57 & & & \\
\hline$\left[\mathrm{CuH}_{12} \mathrm{~L}\right]^{12+}$ & $89.56(3)$ & & & & & & & \\
\hline \multirow[t]{2}{*}[\mathrm{CuH}_{10}\mathrm{L}]{$^{10+}$} & $78.45(2)$ & 569 & 76.68 & 533 & 1.61 & & & $2 \mathrm{~N}_{\mathrm{im}}, 1 \mathrm{~N}^{-}$ \\
\hline & & 311 & 266.94 & 316 & -0.66 & & & \\
\hline$\left[\mathrm{CuH}_{7} \mathrm{~L}\right]^{7+}$ & $60.27(3)$ & & & & & 184.2 & 2.24 & $2 \mathrm{~N}_{\mathrm{im}}, 1 \mathrm{~N}^{-}$ \\
\hline \multirow[t]{2}{*}[\mathrm{CuH}_{6}\mathrm{L}]{$^{6+}$} & $53.22(7)$ & 582 & 87.10 & 540 & 1.18 & & & $2 \mathrm{~N}_{\mathrm{im}}, 1 \mathrm{~N}^{-}$ \\
\hline & & 311 & 313.32 & & & & & \\
\hline$\left[\mathrm{CuH}_{4} \mathrm{~L}\right]^{4+}$ & $40.42(3)$ & & & & & 171 & 2.26 & $2 \mathrm{~N}_{\mathrm{im}}, 1 \mathrm{~N}^{-}$ \\
\hline$\left[\mathrm{CuH}_{2} \mathrm{~L}\right]^{2+}$ & $25.47(3)$ & & & & & 171 & 2.26 & $2 \mathrm{~N}_{\mathrm{im}}, 1 \mathrm{~N}^{-}$ \\
\hline \multirow[t]{3}{*}[\mathrm{CuL}]{} & 7.59 (4) & 585 & 112.20 & 634 & 1.34 & 183 & 2.22 & $2 \mathrm{~N}_{\mathrm{im}}, 2 \mathrm{~N}^{-}$ \\
\hline & & & & 339 & -1.35 & & & \\
\hline & & & & 258 & 6.90 & & & \\
\hline \multirow[t]{4}{*}[\mathrm{CuH}_{-1}\mathrm{L}]{$^{-}$} & $-2.50(3)$ & 555 & 113.91 & 632 & 1.47 & 184 & 2.22 & $2 \mathrm{~N}_{\mathrm{im}}, 2 \mathrm{~N}^{-}$ \\
\hline & & & & 511 & -0.17 & & & \\
\hline & & & & 342 & -0.91 & & & \\
\hline & & & & 258 & 7.54 & & & \\
\hline \multirow[t]{5}{*}[\mathrm{CuH}_{-2}\mathrm{L}]{$^{2-}$} & $-13.45(8)$ & 534 & 127.28 & 638 & 1.47 & 190.8 & 2.205 & $2 \mathrm{~N}_{\mathrm{im}}, 2 \mathrm{~N}^{-}$ \\
\hline & & & & 494 & -0.82 & & & \\
\hline & & & & 358 & -0.13 & & & \\
\hline & & & & 305 & -0.23 & & & \\
\hline & & & & 261 & 8.40 & & & \\
\hline
\end{tabular}

$\mathrm{Cu}^{2+}$ to ligand ratio of $1: 1 \cdot 2 .\left[\mathrm{Cu}^{2+}\right]=0.83 \mathrm{mM}$ 
Table 4 Formation constants of $\mathrm{Zn}^{2+}-\mathrm{MB} 6$ complexes at $298 \mathrm{~K}$ and $I=0.1 \mathrm{M}\left(\mathrm{NaClO}_{4}\right)$

\begin{tabular}{lc}
\hline Complex species & \multicolumn{1}{l}{$\log \beta$} \\
\hline$\left[\mathrm{ZnH}_{20} \mathrm{~L}\right]^{20+}$ & $126.83(10)$ \\
{$\left[\mathrm{ZnH}_{16} \mathrm{~L}\right]^{16+}$} & $108.31(11)$ \\
{$\left[\mathrm{ZnH}_{12} \mathrm{~L}\right]^{12+}$} & $87.92(12)$ \\
{$\left[\mathrm{ZnH}_{8} \mathrm{~L}\right]^{8+}$} & $64.94(12)$ \\
{$\left[\mathrm{ZnH}_{4} \mathrm{~L}\right]^{4+}$} & $39.07(11)$ \\
{$\left[\mathrm{ZnH}_{2} \mathrm{~L}\right]^{2+}$} & $24.31(8)$ \\
{$[\mathrm{ZnL}]$} & $6.58(6)$ \\
\hline
\end{tabular}

Standard deviations in the last figure are shown in parentheses

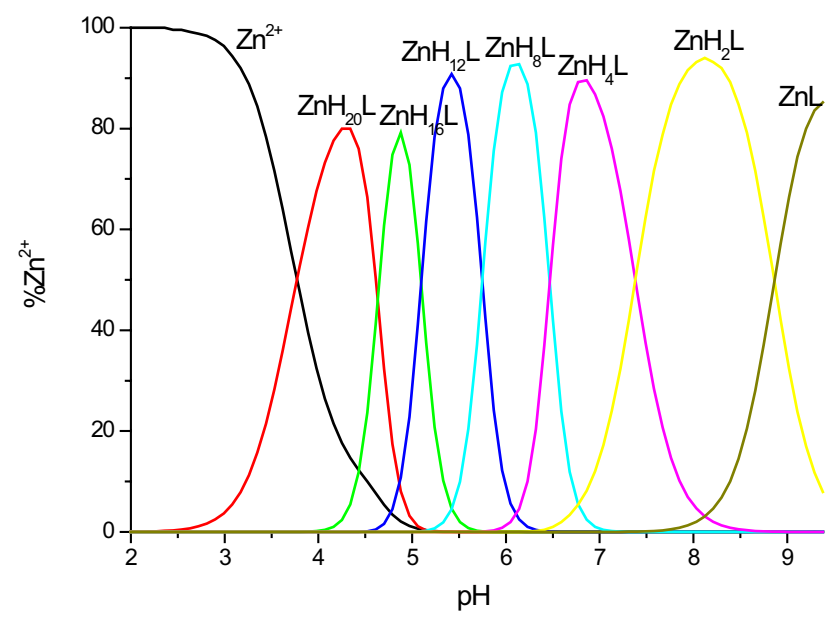

Fig. 4 Species distribution diagram for $\mathrm{Zn}^{2+}-\mathrm{MB} 6$ complexes at 1:2 $\mathrm{Zn}^{2+}$ /peptide ratio; $T=298 \mathrm{~K} ; c_{\text {peptide }}=0.5 \mathrm{mM}$. A higher $\mathrm{Zn}^{2+} /$ peptide ratio triggered precipitation at $\mathrm{pH}$ above 8.5 . For clarity, charges on the speciation plots were omitted

of amide nitrogen to $\mathrm{Cu}^{2+}$ is also supported by the increase intensity of the characteristic band at $313 \mathrm{~nm}[50,60-62]$. EPR parameters at $\mathrm{pH} 4-6$ support the suggested four nitrogen coordination modes for the copper complexes, but also suggest the presence of a trace amount of $3 \mathrm{~N}$ coordinated species, being in equilibria with the $4 \mathrm{~N}$ complex (Table 1). Unfortunately, due to the precipitation observed from $\mathrm{pH}$ around 6.4-9 we were not able to record spectroscopic spectra in this $\mathrm{pH}$ range. At $\mathrm{pH}$ above 9, the differences observed in the UV-Vis and CD spectra support coordination with further amide nitrogen. The coordination mode for $\left[\mathrm{CuH}_{-2} \mathrm{~L}\right]^{2-}$ is $\left\{2 \mathrm{~N}_{\mathrm{im}}, 2 \mathrm{~N}^{-}\right\}$supported by the shift of the $\mathrm{d}-\mathrm{d}$ band from 570 to $551 \mathrm{~nm}$ (Figure S4) and appearance of intense $\mathrm{d}-\mathrm{d}$ band at around 500 and $640 \mathrm{~nm}$ on CD spectra (Figure S5). Comparison of the experimental EPR spectra for $\mathrm{Cu}^{2+}-\mathrm{MB} 3$ systems at $\mathrm{pH} 6$ and $9-10$ show the differences in superhyperfine splitting patterns and especially the changes in the values of $A_{\|}, g_{\|}$and $g^{\perp}$ parameters, confirming the change of the coordination of three and four nitrogen atoms to the $\mathrm{Cu}^{2+}$ ion, respectively [56-58] (Figure S6 and

Table 1). The comparison between splitting patterns due to ${ }^{14} \mathrm{~N}$ hyperfine coupling distinctly reveals the difference between the number of the nitrogen donors in $x y$ coordination plane of $\mathrm{Cu}^{2+}$ for the complexes formed at $\mathrm{pH} 6.62$ and 9.60 [53-55]. A different number of lines is observed, most probably seven and nine, respectively (Figure S6). Significant differences between $g$ and $A$ tensor components $\left(A_{\|}, g_{\|}\right.$and $\left.g^{\perp}\right)$ of the species at $\mathrm{pH} 6.62$ and 9.60 are also observed. The values of EPR parameters correspond to three and four nitrogen donors, respectively (according to Peisach and Blumberg's [52] dependences between $A_{\|}$and $g_{\|}$and the number of nitrogen donors).

\section{$\mathrm{Zn}^{2+}-\mathrm{MB3}$ system}

As in the case of copper complexes, numerous zinc-bound species are observed in the studied $\mathrm{pH}$ range. The titration curves for $\mathrm{Zn}^{2+}-\mathrm{MB} 3$ complexes fit best to the formation of the following complexes: $\left[\mathrm{ZnH}_{16} \mathrm{~L}\right]^{16+},\left[\mathrm{ZnH}_{14} \mathrm{~L}\right]^{14+}$, $\left[\mathrm{ZnH}_{12} \mathrm{~L}\right]^{12+},\left[\mathrm{ZnH}_{10} \mathrm{~L}\right]^{10+},\left[\mathrm{ZnH}_{8} \mathrm{~L}\right]^{8+},\left[\mathrm{ZnH}_{7} \mathrm{~L}\right]^{7+}$, $\left[\mathrm{ZnH}_{6} \mathrm{~L}\right]^{6+},\left[\mathrm{ZnH}_{5} \mathrm{~L}\right]^{5+},\left[\mathrm{ZnH}_{4} \mathrm{~L}\right]^{4+},\left[\mathrm{ZnH}_{3} \mathrm{~L}\right]^{3+},\left[\mathrm{ZnH}_{2} \mathrm{~L}\right]^{2+}$, $[\mathrm{ZnHL}]^{+}$(Fig. 2). The $\mathrm{Zn}^{2+}$ complex formation constants are shown in Table 2. Above $\mathrm{pH}$ 9, precipitation is observed.

In the first complex observed at low $\mathrm{pH},\left[\mathrm{ZnH}_{16} \mathrm{~L}\right]^{16+}$ with maximum concentration at $\mathrm{pH} 4.3$, most likely two imidazole nitrogens are coordinated to the zinc ion $\left\{2 \mathrm{~N}_{\mathrm{im}}\right\}$. In the next species, $\left[\mathrm{ZnH}_{14} \mathrm{~L}\right]^{14+}$, most probably two other imidazoles bind to the central $\mathrm{Zn}^{2+}$ ion, however, due to the lack of spectroscopic data available for $\mathrm{d}^{10}$ metal, this statement is suggested only by the decrease of $\mathrm{pKa}$ for the zinc complex in comparison to the free ligand. The next deprotonations come from other histidine residues which do not participate in binding.

\section{Metal binding stoichiometry of the $\mathrm{Cu}^{2+} / \mathrm{Zn}^{2+}-\mathrm{MB} 6$ system}

Electrospray ionization mass spectrometry confirmed the purity of the studied MB6 ligand (Ac-HHHGAHHAAHHHHAAHHHHHHHHHSHGGAGHGGGAGHH-NH ${ }_{2}$ ) and showed the metal binding stoichiometry at $\mathrm{pH} 6$, indicating that only equimolar species were present under the studied conditions (e.g. $\mathrm{m} / z$ values at 697.46 and 836.55 correspond to $\left[\mathrm{CuLH}_{6}\right]^{6+}$ and $\left[\mathrm{ZnLH}_{5}\right]^{5+}$ complex, respectively), Figure S7. $\mathrm{m} / \mathrm{z}$ values at $1030.21,687.14,589.12$ and 515.61 correspond to $\left[\mathrm{LH}_{4}\right]^{4+},\left[\mathrm{LH}_{6}\right]^{6+},\left[\mathrm{LH}_{7}\right]^{7+}$ and $\left[\mathrm{LH}_{8}\right]^{8+}$ ligand species, respectively (Figure S7 A).

\section{$\mathrm{Cu}^{2+}-\mathrm{MB} 6$ system}

Potentiometric measurements revealed thirteen protonated mononuclear $\mathrm{Cu}^{2+}$ complexes. Distribution diagrams are shown in Fig. 3 and the corresponding stability constants, 

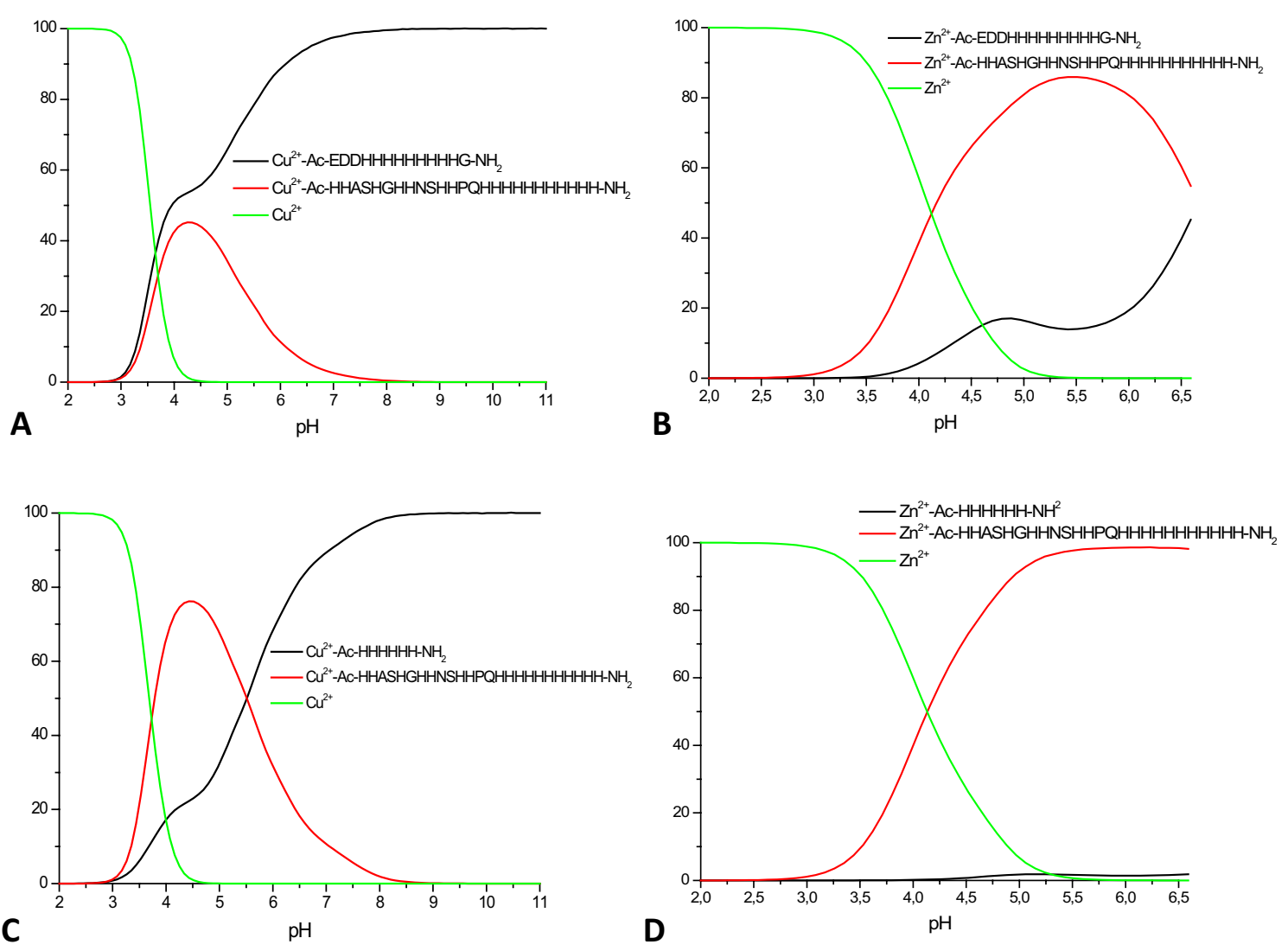

Fig. 5 Competition plots for a $\mathrm{Cu}^{2+}-\mathrm{Ac}-\mathrm{EDDHHHHHHHHHG-}$ $\mathrm{NH}_{2}$ and $\mathrm{Cu}^{2+}-\mathrm{Ac}-\mathrm{HHASHGHHNSHHPQHHHHHHHHHHH-}$ $\mathrm{NH}_{2}$ (MB3); b $\mathrm{Zn}^{2+}-\mathrm{Ac}-\mathrm{EDDHHHHHHHHHG-NH} \mathrm{N}_{2}$ and $\mathrm{Zn}^{2+}$ Ac-HHASHGHHNSHHPQHHHHHHHHHHH-NH ${ }_{2}$ (MB3); c $\mathrm{Cu}^{2+}-\mathrm{Ac}-\mathrm{HHHHHH}-\mathrm{NH}_{2}$ and $\mathrm{Cu}^{2+}-\mathrm{Ac}-\mathrm{HHASHGHHNSHHPQH-}$

together with detailed spectroscopic parameters are reported in Table 3. To investigate the coordination mode of $\mathrm{Cu}^{2+}$ with MB6, we used potentiometric titrations and spectroscopic techniques, such as UV-Vis (Figure S8), CD (Figure S9) and EPR (Figure S10). The first $\mathrm{Cu}^{2+}$ complex detected with the MB6 ligand is $\left[\mathrm{CuH}_{19} \mathrm{~L}\right]^{19+}$, with maximum concentration already at $\mathrm{pH}$ 3.8. In this complex, two imidazole nitrogens are coordinated to $\mathrm{Cu}^{2+}$, which is supported by the $\mathrm{d}-\mathrm{d}$ band at $687 \mathrm{~nm}$ for $\mathrm{pH} 4$ (Figure S8). Next species, $\left[\mathrm{CuH}_{18} \mathrm{~L}\right]^{18+}$ result from the deprotonation and copper(II) ion binding to the third histidine imidazole - the $\mathrm{d}-\mathrm{d}$ band shifts from 687 to $618 \mathrm{~nm}$ in the $\left\{3 \mathrm{~N}_{\mathrm{im}}\right\}$ complex. Moreover, EPR parameters are in good agreement with the $3 \mathrm{~N}$ binding mode (Table 3 ). The coordination of an amide nitrogen occurs at $\mathrm{pH} 4.7$-the maximum concentration of $\left[\mathrm{CuH}_{16} \mathrm{~L}\right]^{16+}$ species, as evidenced by the appearance of an intense $d-d$ band in the $\mathrm{CD}$ spectra (Figure S9). At $\mathrm{pH}$ around 5, a clear shift of the maximum absorption in the direction of shorter wavelengths is observed in the UV-Vis spectra (Figure S8), indicating a $\left\{2 \mathrm{~N}_{\mathrm{im}}, 1 \mathrm{~N}^{-}\right\}$binding mode (one of the imidazoles is substituted by an amide).

HHHHHHHHHH-NH ${ }_{2}$ (MB3); d $\mathrm{Zn}^{2+}-\mathrm{Ac}-\mathrm{HHHHHH}-\mathrm{NH}_{2}$ and $\mathrm{Zn}^{2+}$-Ac-HHASHGHHNSHHPQHHHHHHHHHHH-NH $\mathrm{N}_{2}$ (MB3) complexes. Previously calculated stability constants are applied to a theoretical situation, in which equimolar amounts of $\mathrm{Cu}^{2+} / \mathrm{Zn}^{2+}$ and all ligands are present

For $\left[\mathrm{CuH}_{14} \mathrm{~L}\right]^{14+},\left[\mathrm{CuH}_{12} \mathrm{~L}\right]^{12+},\left[\mathrm{CuH}_{10} \mathrm{~L}\right]^{10+},\left[\mathrm{CuH}_{7} \mathrm{~L}\right]^{7+}$ and $\left[\mathrm{CuH}_{6} \mathrm{~L}\right]^{6+}$ species, present at $\mathrm{pH}$ range 5.2-6.5, no significant changes are observed in the UV-Vis and CD spectra, suggesting that the $\left\{2 \mathrm{~N}_{\mathrm{im}}, 1 \mathrm{~N}^{-}\right\}$donor set does not change and the deprotonations correspond to the proton loss of histidines which are not involved in $\mathrm{Cu}^{2+}$ binding. Similar to the case of the $\mathrm{Cu}^{2+}-\mathrm{MB} 3$ system, due to the precipitation observed at $\mathrm{pH}$ around 6.5-9.3, we were not able to record spectroscopic spectra in this $\mathrm{pH}$ range also for $\mathrm{Cu}^{2+}-\mathrm{MB} 6$ complexes. However, because of the presence of ethylene glycol in EPR measurements, which enhanced the complex solubility, we were able to obtain EPR parameters that also confirmed the $\left\{2 \mathrm{~N}_{\mathrm{im}}, 1 \mathrm{~N}^{-}\right\}$copper binding mode at physiological pH (Table 3, Figure S10). At pH above 9, the differences in the $d-d$ transition energy [a shift of the band to shorter wavelengths and appearance of new $d-d$ bands in the CD spectra (Figures S8 and S9)] strongly support the coordination mode with an additional amide nitrogen - the coordination mode for $[\mathrm{CuL}],\left[\mathrm{CuH}_{-1} \mathrm{~L}\right]^{-}$and $\left[\mathrm{CuH}_{-2} \mathrm{~L}\right]^{2-}$ complexes is $\left\{2 \mathrm{~N}_{\mathrm{im}}, 2 \mathrm{~N}^{-}\right\}$. The $4 \mathrm{~N}$ coordination is supported also by the EPR parameter $g_{\|}$in the range $2.22-2.205$. 

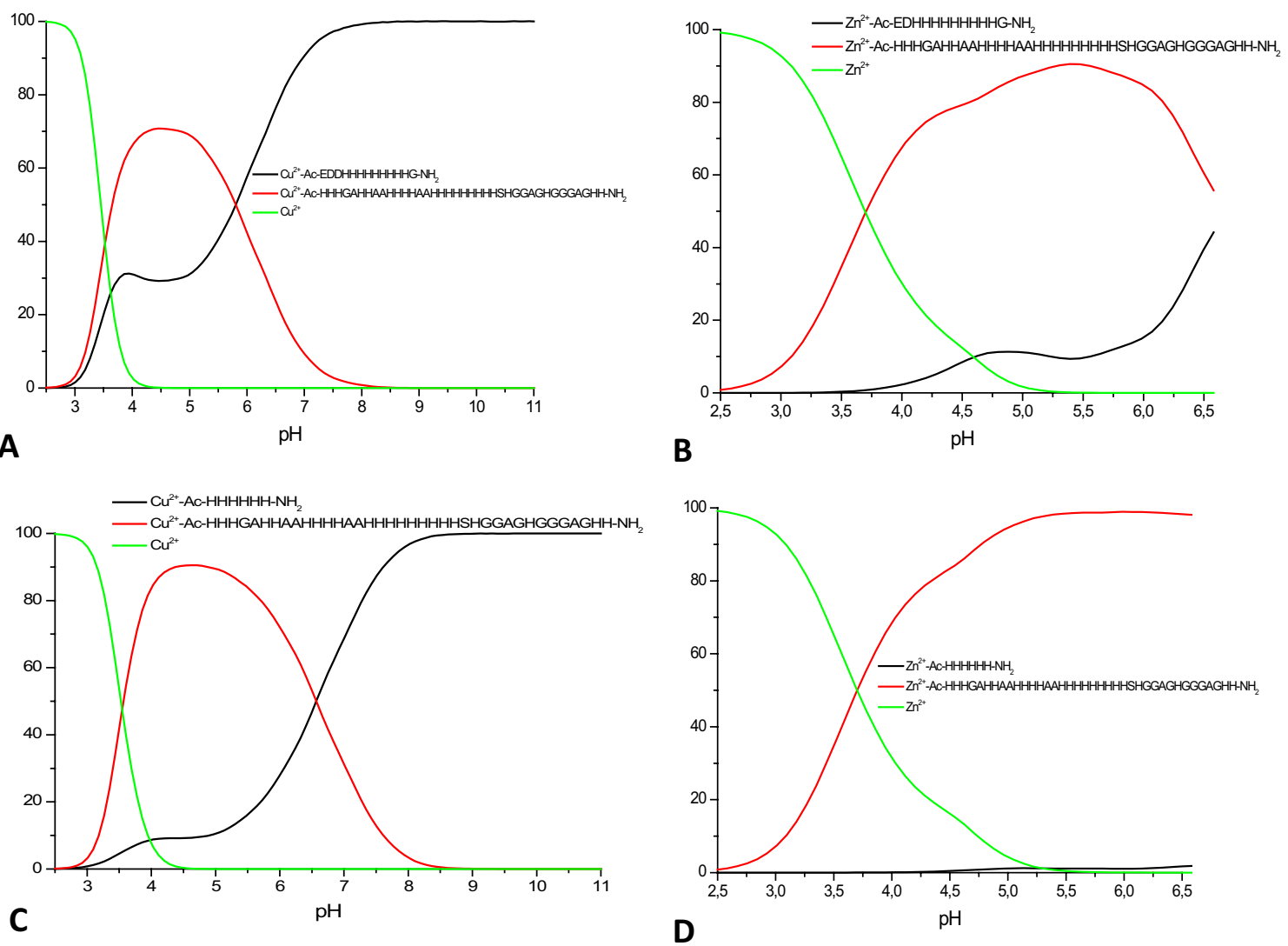

Fig. 6 Competition plots for a $\mathrm{Cu}^{2+}-\mathrm{Ac}-\mathrm{EDDHHHHHH}-$ HHHG-NH $\mathrm{N}_{2}$ and $\mathrm{Cu}^{2+}-\mathrm{Ac}-\mathrm{HHHGAHHAAHHHHAAH-}$ HHHHHHHHSHGGAGHGGGAGHH-NH ${ }_{2}$ (MB6); b $\mathrm{Zn}^{2+}-\mathrm{Ac}-\mathrm{EDHHHHHHHHHG-NH} \mathrm{H}_{2}$ and $\mathrm{Zn}^{2+}-\mathrm{Ac}-\mathrm{HHHGAH}-$ HAAHHHHAAHHHHHHHHHSHGGAGHGGGAGHH-NH (MB6); $\mathrm{c} \mathrm{Cu}^{2+}-\mathrm{Ac}-\mathrm{HHHHHH}-\mathrm{NH}_{2}$ and $\mathrm{Cu}^{2+}-\mathrm{Ac}-\mathrm{HHHGAHHAAH-}$

\section{$\mathrm{Zn}^{2+}-\mathrm{MB6}$ system}

HHHAAHHHHHHHHHSHGGAGHGGGAGHH-NH ${ }_{2}$ (MB6); d $\mathrm{Zn}^{2+}-\mathrm{Ac}-\mathrm{HHHHHH}-\mathrm{NH}_{2}$ and $\mathrm{Zn}^{2+}-\mathrm{Ac}-\mathrm{HHHGAHHAAHHH}-$ HAAHHHHHHHHHSHGGAGHGGGAGHH-NH ${ }_{2}$ (MB6) complexes. Previously calculated stability constants are applied to a theoretical situation, in which equimolar amounts of $\mathrm{Cu}^{2+} / \mathrm{Zn}^{2+}$ and all ligands are present

The MB6 peptide forms seven complex species with $\mathrm{Zn}^{2+}$ ions, with the stoichiometry and species distribution shown in Table 4 and Fig. 4. In the $\mathrm{Zn}^{2+}-\mathrm{MB} 6$ system, the first complex species, $\left[\mathrm{ZnH}_{20} \mathrm{~L}\right]^{20+}$, reaches a maximum concentration at $\mathrm{pH} 4$ (Fig. 4). In this complex, it is expected that two imidazole nitrogen atoms are bound to zinc ions. In the next formed species, $\left[\mathrm{ZnH}_{16} \mathrm{~L}\right]^{16+}$, most likely another two imidazoles coordinate to the central zinc atom, and two others deprotonate without binding — however, both statements are only a hypothesis, since no stepwise deprotonations are observed and no spectroscopic data are available for the $\mathrm{d}^{10}$ metal; it is also probable that three imidazole nitrogens are bound at this point. The next deprotonations most like are due to the loss of protons from unbound His side chains.

\section{Discussion}

What is the impact of the presence of the extraordinarily high number of histidines on the stability of the complexes they form with $\mathrm{Cu}^{2+}$ and $\mathrm{Zn}^{2+}$ ions? Naturally, the availability of imidazole nitrogen donors is very likely to enhance metal complex stability (even statistically, there is a higher chance to encounter this potential metal binder), but the answer is not as trivial as it may seem. To discuss complex stability, we compared so-called competition plots-they are based on the calculated formation constants and describe a hypothetical situation, in which equimolar amounts of the metal ion and two multi-histidine ligands are present in solution at different $\mathrm{pH}$ values (Figs. 5, 6). We compared our MB3 and MB6 ligands with two other His-rich peptides, a typical (His) ${ }_{6} \operatorname{tag}\left(\mathrm{Ac}-\mathrm{HHHHHH}-\mathrm{NH}_{2}\right)$ and a snake venom peptide fragment with nine consecutive histidines (Ac-EDDHHHHHHHHH-NH ${ }_{2}$ ) [1, 2, 41, 42]. In the case of zinc complexes, the outcome of these comparisons is easier to explain-both our 18-His and 22-His fragments (MB3 
and MB6, respectively) bind $\mathrm{Zn}^{2+}$ with higher affinity than the $\mathrm{His}_{6}$-tag and the 9-His fragment (Figs. 5b, d, 6b, d) the higher number of potential binding sites enhances complex stability. It is worth to notice that while the $\mathrm{His}_{6}$-tag is almost entirely outcompeted by the 18-His and 22-His MB3 and MB6, in the case of the 9-His fragment, the difference is not as striking - this would again confirm the straightforward conclusion - the more histidines, the more stable the zinc complex (Figure S11 A).

The comparison becomes far less trivial in the case of copper(II), which is able to deprotonate and bind to amide nitrogens. For the $\mathrm{His}_{6}$-tag, below pH 6, the outcome is easy to interpret-MB3 and MB6 form more stable complexes with $\mathrm{Cu}^{2+}$ (Figs. 5c, 6c). For the 9-His fragment, the difference in stability is either not as pronounced (in the case of MB6, Fig. 6a) or comparable (for MB3, Fig. 5a). The really interesting situation starts above $\mathrm{pH} 6.5$ - the copper complexes with the shorter fragments become far more stable than the $\mathrm{Cu}^{2+}$ ones with 18 -His and 22-His MB3 and MB6. How to explain this phenomenon? At this $\mathrm{pH}$, in the case of the two shorter fragments, amide nitrogens start to participate in the binding [1]. Amide binding to $\mathrm{Cu}^{2+}$ results in the formation of thermodynamically very stable five and six membered chelate rings, making the complexes more stable than those in which $\mathrm{Cu}^{2+}$ is bound to the same number of imidazole nitrogens. Also MB3 has a higher affinity for copper than longer MB6 fragment (Figure S11 B). This is in good agreement with what we already show-less histidines there are in the sequence, the sooner the amides start to participate in the binding and the more stable the complex is. Why do amide nitrogens start bind to $\mathrm{Cu}^{2+}$ at lower $\mathrm{pH}$ in the case of shorter fragments, with respect to the multihistidine MB3 and MB6 ligands? We can hypothesize that this is due to (1) the presence of so-called polymorphic binding states, where the metal "moves back and forth" along such regions [2] - most likely, the more His residues are present, the more likely the metal is to "move"; (2) stacking interactions within the ligand, which allow amide deprotonation only at higher $\mathrm{pH}[63]$.

Acknowledgements This work is dedicated to Prof. Helmut Sigel, an extraodinary scientist and friend, with our best birthday wishes. The work was supported by the Wroclaw Centre of Biotechnology, programme The Leading National Research Centre (KNOW). MRZ would like to acknowledge the National Science Centre (nr UMO2014/13/D/ST5/02868) and the Ministry of Science and Higher Research (0420/2655/17).

Open Access This article is distributed under the terms of the Creative Commons Attribution 4.0 International License (http://creativecommons.org/licenses/by/4.0/), which permits unrestricted use, distribution, and reproduction in any medium, provided you give appropriate credit to the original author(s) and the source, provide a link to the Creative Commons license, and indicate if changes were made.

\section{References}

1. Watly J, Simonoysky E, Wieczorek R, Barbosa N, Miller Y, Kozlowski H (2014) Inorg Chem 53:6675-6683

2. Watly J, Simonovsky E, Barbosa N, Spodzieja M, Wieczorek R, Rodziewicz-Motowidlo S, Miller Y, Kozlowski H (2015) Inorg Chem 54:7692-7702

3. Sovago I, Kallay C, Varnagy K (2012) Coord Chem Rev 256:2225-2233

4. Pontecchiani F, Simonovsky E, Wieczorek R, Barbosa N, Rowinska-Zyrek M, Potocki S, Remelli M, Miller Y, Kozlowski H (2014) Dalton Trans 43:16680-16689

5. Schmitt-Ulms G, Ehsani S, Watts JC, Westaway D, Wille H (2009) PLoS One 4:13

6. Nishida S, Mizuno T, Obata H (2008) Plant Physiol Biochem 46:601-606

7. Valensin G, Molteni E, Valensin D, Taraszkiewicz M, Kozlowski H (2009) J Phys Chem B 113:3277-3279

8. Gralka E, Valensin D, Porciatti E, Gajda C, Gaggelli E, Valensin G, Kamysz W, Nadolny R, Guerrini R, Bacco D, Remelli M, Kozlowski H (2008) Dalton Trans 5207-5219

9. Kozlowski H, Janicka-Klos A, Stanczak P, Valensin D, Valensin G, Kulon K (2008) Coord Chem Rev 252:1069-1078

10. Stanczak P, Juszczyk P, Grzonka Z, Kozlowski H (2007) FEBS Lett 581:4544-4548

11. Hecel A, Migliorini C, Valensin D, Luczkowski M, Kozlowski H (2015) Dalton Trans 44:13125-13132

12. Witkowska D, Rowinska-Zyrek M, Valensin G, Kozlowski H (2012) Coord Chem Rev 256:133-148

13. Zeng YB, Zhang DM, Li HY, Sun HZ (2008) J Biol Inorg Chem 13:1121-1131

14. Zeng YB, Yang N, Sun HZ (2011) Chem Eur J 17:5852-5860

15. Seshadri S, Benoit SL, Maier RJ (2007) J Bacteriol 189:4120-4126

16. Olson JW, Mehta NS, Maier RJ (2001) Mol Microbiol 39:176-182

17. Witkowska D, Politano R, Rowinska-Zyrek M, Guerrini R, Remelli M, Kozlowski H (2012) Chem Eur J 18:11088-11099

18. Rowinska-Zyrek M, Potocki S, Witkowska D, Valensin D, Kozlowski H (2013) Dalton Trans 42:6012-6020

19. Favreau P, Cheneval O, Menin L, Michalet S, Gaertner H, Principaud F, Thai R, Menez A, Bulet P, Stocklin R (2007) Rapid Commun Mass Spectrom 21:406-412

20. Wagstaff SC, Favreau P, Cheneval O, Laing GD, Wilkinson MC, Miller RL, Stocklin R, Harrison RA (2008) Biochem Biophys Res Commun 365:650-656

21. van Kan EJM, Demel RA, van der Bent A, de Kruijff B (2003) Biochim Biophys Acta Biomembr 1615:84-92

22. Epand RM, Vogel HJ (1999) Biochim Biophys Acta Biomembr 1462:11-28

23. MacQuarrie JL, Stafford AR, Yau JW, Leslie BA, Vu TT, Fredenburgh JC, Weitz JI (2011) Blood 117:4134-4141

24. Poon IKH, Patel KK, Davis DS, Parish CR, Hulett MD (2011) Blood 117:2093-2101

25. Knecht S, Ricklin D, Eberle AN, Ernst B (2009) J Mol Recognit 22:270-279

26. Waugh DS (2005) Trends Biotechnol 23:316-320

27. Zoroddu MA, Kowalik-Jankowska T, Medici S, Peana M, Kozlowski H (2008) Dalton Trans (44):6127-6134. https://doi. org/10.1039/b808600a

28. Peana M, Medici S, Nurchi VM, Crisponi G, Zoroddu MA (2013) Coord Chem Rev 257:2737-2751

29. Zoroddu MA, Medici S, Peana M (2009) J Inorg Biochem 103:1214-1220 
30. Huntley MA, Golding GB (2002) Proteins Struct Funct Genet 48:134-140

31. Karlin S, Brocchieri L, Bergman A, Mrazek J, Gentles AJ (2002) Proc Natl Acad Sci USA 99:333-338

32. Alba MM, Santibanez-Koref MF, Hancock JM (1999) J Mol Evol 49:789-797

33. Alba MM, Guigo R (2004) Genome Res 14:549-554

34. Faux NG, Bottomley SP, Lesk AM, Irving JA, Morrison JR, de la Banda MC, Whisstock JC (2005) Genome Res 15:537-551

35. Gamsjaeger R, Liew CK, Loughlin FE, Crossley M, Mackay JP (2007) Trends Biochem Sci 32:63-70

36. Hoque M, Young TM, Lee CG, Serrero G, Mathews MB, Pe'ery T (2003) Mol Cell Biol 23:1688-1702

37. Taube R, Lin X, Irwin D, Fujinaga K, Peterlin BM (2002) Mol Cell Biol 22:321-331

38. Alvarez M, Estivill X, de la Luna S (2003) J Cell Sci 116:3099-3107

39. Salichs E, Ledda A, Mularoni L, Alba MM, de la Luna S (2009) PLoS Genet 5:18

40. Rowinska-Zyrek M, Witkowska D, Potocki S, Remelli M, Kozlowski H (2013) New J Chem 37:58-70

41. Brasili D, Watly J, Simonovsky E, Guerrini R, Barbosa NA, Wieczorek R, Remelli M, Kozlowski H, Miller Y (2016) Dalton Trans 45:5629-5639

42. Watly J, Hecel A, Rowinska-Zyrek M, Kozlowski H (2017) Inorg Chim Acta. https://doi.org/10.1016/j.ica.2017.06.053

43. Tan K, Shaw AL, Madsen B, Jensen K, Taylor-Papadimitriou J, Freemont PS (2003) J Biol Chem 278:20507-20513

44. Kataoka K, Han SI, Shioda S, Hirai M, Nishizawa M, Handa H (2002) J Biol Chem 277:49903-49910

45. Zhao L, Guo M, Matsuoka TA, Hagman DK, Parazzoli SD, Poitout V, Stein R (2005) J Biol Chem 280:11887-11894

46. Rocques N, Abou Zeid N, Sii-Felice K, Lecoin L, Felder-Schmittbuhl MP, Eychene A, Pouponnot C (2007) Mol Cell 28:584-597
47. Gran G (1950) Acta Chem Scand 4:559-577

48. Gans P, Sabatini A, Vacca A (1996) Talanta 43:1739-1753

49. Vuceta J, Morgan JJ (1977) Limnol Oceanogr 22:742-746

50. Pettit LD, Pyburn S, Bal W, Kozlowski H, Bataille M (1990) J Chem Soc Dalton Trans 3565-3570. https://doi.org/10.1039/ DT9900003565

51. Alderighi L, Gans P, Ienco A, Peters D, Sabatini A, Vacca A (1999) Coord Chem Rev 184:311-318

52. Peisach J, Blumberg WE (1974) Arch Biochem Biophys 165:691-708

53. Kotynia A, Bielinska S, Kamysz W, Brasun J (2012) Dalton Trans 41:12114-12120

54. Kotynia A, Czyznikowska Z, Bielinska S, Szyrwiel L, Kamysz W, Malinka W, Brasun J (2014) New J Chem 38:5198-5206

55. Kowalik-Jankowska T, Rajewska A, Wisniewska K, Grzonka Z, Jezierska J (2005) J Inorg Biochem 99:2282-2291

56. Denblaauwen T, Canters GW (1993) J Am Chem Soc 115:1121-1129

57. Calvo R, Passeggi MCG, Isaacson RA, Okamura MY, Feher G (1990) Biophys J 58:149-165

58. Bonomo RP, Riggi F, Dibilio AJ (1988) Inorg Chem 27:2510-2512

59. Sigel H, Martin RB (1982) Chem Rev 82:385-426

60. Osz K, Nagy Z, Pappalardo G, Di Natale G, Sanna D, Micera G, Rizzarelli E, Sovago I (2007) Chem Eur J 13:7129-7143

61. Berti F, Gaggelli E, Guerrini R, Janicka A, Kozlowski H, Legowska A, Miecznikowska H, Migliorini C, Pogni R, Remelli M, Rolka K, Valensin D, Valensin G (2007) Chem Eur J 13:1991-2001

62. Remelli M, Valensin D, Bacco D, Gralka E, Guerrini R, Migliorini C, Kozlowski H (2009) New J Chem 33:2300-2310

63. Bissantz C, Kuhn B, Stahl M (2010) J Med Chem 53:5061-5084 